Supplement of Hydrol. Earth Syst. Sci., 19, 3633-3651, 2015

http://www.hydrol-earth-syst-sci.net/19/3633/2015/

doi:10.5194/hess-19-3633-2015-supplement

(C) Author(s) 2015. CC Attribution 3.0 License.

(c) (i)

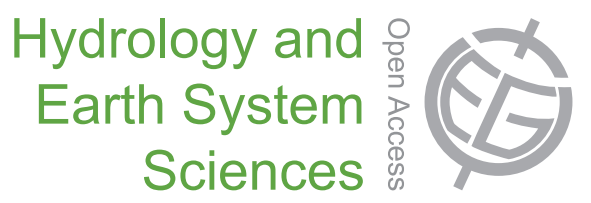

Supplement of

\title{
Isolating the impacts of land use and climate change on streamflow
}

I. Chawla and P. P. Mujumdar

Correspondence to: P. P. Mujumdar (pradeep@ civil.iisc.ernet.in)

The copyright of individual parts of the supplement might differ from the CC-BY 3.0 licence. 
Analysis presented in section 3.3.1 indicate that LU affects the peak discharge rather than the total streamflow amount. Therefore, analysis on the smaller time scale may provide deeper insight into the contribution of LU to streamflow response. Considering this, contribution of LU and climate to the streamflow response is isolated at the monthly scale. The results pertaining to the JJAS (monsoon) months, during when peak flow occurs in the region, are presented in Table S1 in this discussion.

Results from the Table S1 suggest that climate is the major contributor to the streamflow across all the three regions at monthly scale. The rather negligible contribution of LU to streamflow can be attributed to the low spatial extent of the sensitive LU category (urban area) in the three regions. However, when compared with the results of analysis at annual scale, contribution of LU to streamflow is slightly higher for upstream and midstream regions during JJAS months which emphasizes the fact that LU affects the peak discharge from the basin. For the downstream region, in addition to the low spatial extent of the urban area, streamflow response is observed to be moderately sensitive to the changes in this LU category (Table 4 of the manuscript). This could be the plausible reason for the negligible contribution of the LU to streamflow from the downstream region. This observation is consistent with the results obtained from the analysis on the impact of land use change on streamflow under invariant climate (Sect. 3.3.1), wherein negligible change in the discharge for the downstream region is noticed during the time period 1971 to 2011. On assessing the contribution of LU to streamflow across different time periods, it is observed that contribution during period P4 is higher for upstream and midstream regions compared to the contribution during period P1, indicating the influence of gradual increase in the urban area over the peak flows across the regions. 
Table S1. Contribution of climate and LU to the streamflow for different time periods during monsoon months

\begin{tabular}{|c|c|c|c|c|c|c|c|c|c|c|c|c|c|c|c|c|c|}
\hline \multirow[t]{2}{*}{ Region } & \multirow{2}{*}{ Streamflow } & \multicolumn{4}{|c|}{$\begin{array}{c}\text { P1 } \\
(1971-1980)\end{array}$} & \multicolumn{4}{|c|}{$\begin{array}{c}\text { P2 } \\
(1981-1990)\end{array}$} & \multicolumn{4}{|c|}{$\begin{array}{c}\text { P3 } \\
(1991-2000) \\
\end{array}$} & \multicolumn{4}{|c|}{$\begin{array}{c}\text { P4 } \\
(2001-2005)\end{array}$} \\
\hline & & Jun & Jul & Aug & Sep & Jun & Jul & Aug & Sep & Jun & Jul & Aug & Sep & Jun & Jul & Aug & Sep \\
\hline \multirow{5}{*}{ Upstream } & $Q_{\text {int }}\left(m^{3} s^{-1}\right)$ & 782 & 1656 & 1920 & 1224 & 568 & 1572 & 1952 & 1141 & 762 & 1579 & 2339 & 1576 & 681 & 1921 & 2204 & 1523 \\
\hline & $Q_{\text {clim }}\left(\mathrm{m}^{3} \mathrm{~s}^{-1}\right)$ & 768 & 1610 & 1869 & 1196 & 548 & 1487 & 1840 & 1082 & 741 & 1505 & 2220 & 1499 & 649 & 1777 & 2044 & 1401 \\
\hline & $Q_{\text {clim }}(\%)$ & 98 & 97 & 97 & 98 & 96 & 95 & 94 & 95 & 97 & 95 & 95 & 95 & 95 & 92 & 93 & 92 \\
\hline & $Q_{\mathrm{LU}}\left(\mathrm{m}^{3} \mathrm{~s}^{-1}\right)$ & 15 & 46 & 51 & 28 & 20 & 85 & 112 & 59 & 21 & 74 & 119 & 78 & 31 & 144 & 160 & 122 \\
\hline & $Q_{\mathrm{LU}}(\%)$ & 2 & 3 & 3 & 2 & 4 & 5 & 6 & 5 & 3 & 5 & 5 & 5 & 5 & 8 & 7 & 8 \\
\hline \multirow{5}{*}{ Midstream } & $Q_{\text {int }}\left(\mathrm{m}^{3} \mathrm{~s}^{-1}\right)$ & 1007 & 2766 & 3425 & 2492 & 719 & 2814 & 3839 & 2755 & 921 & 2584 & 4130 & 3403 & 981 & 2811 & 3016 & 3907 \\
\hline & $Q_{\text {clim }}\left(m^{3} s^{-1}\right)$ & 991 & 2679 & 3367 & 2458 & 681 & 2606 & 3526 & 2592 & 852 & 2323 & 3745 & 3144 & 909 & 2520 & 2724 & 3597 \\
\hline & $Q_{\text {clim }}(\%)$ & 98 & 97 & 98 & 99 & 95 & 93 & 92 & 94 & 92 & 90 & 91 & 92 & 93 & 90 & 90 & 92 \\
\hline & $Q_{\mathrm{LU}}\left(\mathrm{m}^{3} \mathrm{~s}^{-1}\right)$ & 16 & 87 & 58 & 34 & 38 & 208 & 313 & 164 & 69 & 261 & 385 & 259 & 73 & 292 & 292 & 310 \\
\hline & $Q_{\mathrm{LU}}(\%)$ & 2 & 3 & 2 & 1 & 5 & 7 & 8 & 6 & 8 & 10 & 9 & 8 & 7 & 10 & 10 & 8 \\
\hline \multirow{5}{*}{ Downstream } & $Q_{\text {int }}\left(\mathrm{m}^{3} \mathrm{~s}^{-1}\right)$ & 63 & 263 & 382 & 242 & 43 & 226 & 282 & 286 & 13 & 13 & 301 & 288 & 69 & 193 & 205 & 293 \\
\hline & $Q_{\text {clim }}\left(\mathrm{m}^{3} \mathrm{~s}^{-1}\right)$ & 63 & 260 & 379 & 240 & 43 & 224 & 281 & 284 & 13 & 13 & 299 & 286 & 69 & 192 & 204 & 293 \\
\hline & $Q_{\text {clim }}(\%)$ & 100 & 99 & 99 & 99 & 100 & 99 & 100 & 100 & 100 & 100 & 99 & 99 & 99 & 99 & 100 & 100 \\
\hline & $Q_{\mathrm{LU}}\left(\mathrm{m}^{3} \mathrm{~s}^{-1}\right)$ & 0 & 3 & 3 & 2 & 0 & 2 & 1 & 1 & 0 & 0 & 3 & 3 & 1 & 1 & 0 & 0 \\
\hline & $Q_{\mathrm{LU}}(\%)$ & 0 & 1 & 1 & 1 & 0 & 1 & 0 & 0 & 0 & 0 & 1 & 1 & 1 & 1 & 0 & 0 \\
\hline
\end{tabular}


